\title{
Pengembangan, Uji Validitas dan Reliabilitas Tes Diagnostik Five-Tier untuk Materi Getaran Harmonis Sederhana beserta Hasil Uji Coba Terbatasnya
}

\author{
Widiya K. Putri dan Frida U. Ermawati* \\ Jurusan Fisika, FMIPA, Universitas Negeri Surabaya (UNESA) \\ *Email: frida.ermawati@unesa.ac.id
}

DOI: https://doi.org/10.33369/pendipa.5.1.92-101

\begin{abstract}
[Development, Validity and Reliability of Five-Tier Diagnostic Test for Simple Harmonic Motion Concept and The Limited Trial Result] In learning Physics, it has been found that many students experienced misconceptions, for example in the Simple Harmonic Motion (SHM) concept. These misconceptions must be identified immediately using diagnostic tests, one of which is in the five-tier format. This paper reports the results of the development of a five-tier diagnostic test instrument for SHM concept, the results of its validity, reliability and limited trials to a number of students, considering that such an instrument is not yet available. For this reason, the research \& development method is adopted. There are 16 items that are ready to be tested. Validity test includes internal and external validity. Internal validity was carried out by two appointed UNESA Physics Lecturers. External validity includes content and construct validity. Content validity was determined based on the \% of false positives (FP) and false negatives (FN) which must be $<10 \%$. Construct validity was determined based on Pearson Product Moment $\left(r_{x y}\right)$ correlation. While the reliability is determined based on the Cronbach Alpha coefficient $\left(r_{11}\right)$ with $r_{\text {theory }}=0.413\left(5 \%\right.$ significance level). The $F P=0.6 \%, F N=2.4 \%, r_{x y}=0.659$ and $r_{11}=0.869$ so that the instrument is valid and reliable. The limited trial showed that at least $50 \%$ of the total students experienced a lack of knowledge on the SHM concept. These findings also confirm that physics is a difficult subject for students.
\end{abstract}

Keywords: Five-tier diagnostic test, Simple Harmonic Motion, validity, reliability, conception level

\begin{abstract}
ABSTRAK
Pada pembelajaran Fisika, banyak ditemukan siswa yang mengalami miskonsepsi, sebagai misal pada konsep Getaran Harmonis Sederhana (GHS). Miskonsepsi tersebut harus segera diidentifikasi menggunakan tes diagnostik, salah satunya berformat five-tier. Makalah ini melaporkan hasil pengembangan instrumen tes diagnostik five-tier untuk materi GHS, hasil uji validitas, reliabilitas dan uji coba terbatasnya kepada sejumlah siswa, mengingat instrumen semacam itu belum tersedia. Untuk itu metode research \& development diadopsi. Diperoleh 16 butir soal yang siap diuji cobakan. Uji validitas meliputi validitas internal dan eksternal. Validitas internal dilakukan oleh dua orang Dosen Fisika UNESA yang ditunjuk. Validitas eksternal meliputi validitas isi dan konstruk. Validitas isi ditentukan berdasarkan \% false positive $(F P)$ dan false negative $(F N)$ yang harus $<10 \%$. Validitas konstruk ditentukan berdasarkan korelasi Pearson Product Moment $\left(\mathrm{r}_{\mathrm{xy}}\right)$. Sedangkan reliabilitas ditentukan berdasarkan koefisien Alpha Cronbach $\left(\mathrm{r}_{11}\right)$ dengan $\mathrm{r}_{\text {teori }}=0,413$ (taraf signifikansi $5 \%$ ). Diperoleh $F P=0,6 \%, F N=2,4 \%, \mathrm{r}_{\mathrm{xy}}=0,659$ dan $\mathrm{r}_{11}=0,869$ sehingga instrumen tersebut valid dan reliabel. Uji coba terbatas menunjukkan bahwa setidaknya 50\% dari total siswa uji mengalami lack of knowledge terhadap konsep GHS. Temuan ini sekaligus mengkonfirmasi bahwa Fisika adalah pelajaran yang sulit bagi siswa.
\end{abstract}

Kata kunci: tes diagnostik five-tier, Getaran Harmonis Sederhana, validitas, reliabilitas, level konsepsi 


\section{PENDAHULUAN}

Dalam pembelajaran Fisika, kunci utama yang harus dimiliki oleh siswa adalah penguasaan konsep (Rafiqah, Amin, \& Wayong, 2019). Namun kenyataannya, penguasaan konsep tersebut tidak dapat terwujud dengan mudah. Kesulitan pemahaman konsep tersebut ditemukan dalam Hukum Newton (Sari, Parno, \& Taufiq, 2018), Fluida Statis (Prastiwi, Parno, \& Wisodo, 2018), Suhu dan Kalor (Azizah, Parno, \& Supriana, 2019). Kesulitan pemahaman konsep tersebut juga ditemukan saat Penulis menjadi pengajar privat bagi empat orang siswa kelas XI di salah satu SMA Negeri di wilayah Kabupaten Mojokerto, namun pada materi Getaran Harmonis Sederhana (GHS). Kesulitan pemahaman konsep tersebut terjadi pada beberapa sub materi, khususnya pada sub materi gaya pemulih bandul $(\mathrm{Fp})$ dan periode getaran (T).

Kesulitan pemahaman konsep tersebut ditemukan ketika Penulis menyodorkan ilustrasi dari dua bandul, yaitu Bandul 1 dan Bandul 2. Kedua bandul tersebut memiliki massa yang berbeda $\left(\mathrm{m}_{2}=2 \mathrm{~m}_{1}\right)$ namun memiliki panjang tali yang sama $\left(\ell_{1}=\ell_{2}\right)$ dan keduanya juga disimpangkan dengan sudut yang sama, yaitu $\theta_{1}=\theta_{2}=10^{\circ}$. Kemudian siswa diminta untuk menentukan perbandingan antara nilai periode getaran Bandul 1 dengan nilai periode getaran Bandul $2\left(\mathrm{~T}_{1}: \mathrm{T}_{2}\right)$. Siswa menganggap bahwa perbandingan antara nilai periode getaran tersebut sebanding dengan massa dari masingmasing bandul. Mereka beranggapan bahwa bandul dengan massa yang lebih besar $\left(\mathrm{m}_{2}\right)$ akan bergerak lebih lambat daripada bandul dengan massa yang lebih kecil $\left(m_{1}\right)$. Sementara menurut konsep Fisika, apabila kedua bandul tersebut disimpangkan dengan sudut $(\theta)$ yang sama, maka kedua bandul tersebut akan menempuh satu getaran dalam waktu yang sama. Menurut Young \& Freedman (2013) dalam bukunya yang berjudul: "University Physics with Modern Physics", "the period, $T$, is the time for one cycle". Artinya, periode (T) merupakan waktu yang diperlukan oleh bandul untuk menempuh satu getaran penuh. Menurut Young \& Freedman (2013) dalam buku yang sama, nilai Periode Getaran bandul tersebut dapat dituliskan dalam Pers. 1:

$$
T=2 \pi \frac{\ell}{g}
$$

Dimana, $T$ (s) merupakan Periode getaran, $\ell(\mathrm{m})$ merupakan panjang tali dan $\mathrm{g}\left(\mathrm{m} / \mathrm{s}^{2}\right)$ merupakan percepatan gravitasi.

Berdasarkan Pers. 1, dapat dipahami bahwa periode getaran Bandul 1 dan periode getaran Bandul 2 dipengaruhi oleh panjang tali yang digunakan dan percepatan gravitasi di tempat itu, namun tidak dipengaruhi oleh massa beban yang digunakan.

Berdasarkan definisi periode getaran bandul di atas, maka pemahaman siswa yang menganggap bahwa periode getaran sebanding dengan massa bandul adalah tidak benar. Ketidaksesuaian antara pemahaman yang dimiliki oleh siswa dengan konsep Fisika yang sebenarnya tersebut dinamakan dengan miskonsepsi (Jannah \& Ermawati, 2019). Miskonsepsi pada materi GHS tersebut harus segera diatasi sedini mungkin agar tidak mengganggu pembelajaran pada materi selanjutnya. Cara yang dapat dilakukan untuk mendeteksi adanya miskonsepsi pada siswa tersebut adalah peta konsep, wawancara mengenai konsep dan tes diagnostik (Ali, 2019).

Diantara ketiga cara tersebut, tes diagnostik adalah cara yang lebih efisien untuk mendeteksi miskonsepsi (Salsabila \& Ermawati, 2020). Sejauh ini, telah banyak dikembangkan tes diagnostik miskonsepsi, mulai dari tes diagnostik tingkat pertama (one tier) hingga tes diagnostik tingkat kelima (five tier). Tes diagnostik one tier telah digunakan pada materi Termodinamika (Pratiwi , 2016) dan Hukum Newton (Lely, Silitonga, \& Oktavianty, 2018). Tes diagnostik two tier telah digunakan pada materi Konsep dan Fenomena Kuantum (Ramadhan, Dwijananti, \& Wahyuni, 2018), Usaha dan Energi (Zafitri, Fitriyanto, \& Yah, 2018). Tes diagnostik berikutnya, yaitu three tier telah digunakan pada materi Alat Optik (Munawaroh \& Setyarsih, 2016) dan Konstanta Pegas (Maulini, Kurniawan, \& Muliyani, 2017). Tes diagnostik four tier telah digunakan pada materi Suhu, Kalor dan Perpindahannya (Utari \& Ermawati, 2018), Dinamika Rotasi Kesetimbangan Benda Tegar (Jannah \& Ermawati, 2019). Sedangkan tes diagnostik five tier telah digunakan pada materi 
Vektor (Qonita \& Ermawati, 2020) dan Elastisitas (Salsabila \& Ermawati, 2020).

Tes diagnostik five-tier tersebut terdiri dari pertanyaan, tingkat keyakinan jawaban, alasan, tingkat keyakinan alasan dan satu pertanyaan tambahan yang bersifat terbuka. Penambahan satu butir pertanyaan pada tes diagnostik miskonsepsi tersebut dapat mengatasi kemungkinan adanya tebakan yang dilakukan oleh siswa (Bayuni, Sopandi, \& Sujana , 2018). Satu butir pertanyaan tambahan tersebut dapat berupa drawing test (tes menggambar), penarikan kesimpulan atau tes yang lain sesuai dengan kebutuhan dari masing-masing butir soal (Anam, 2019). Melalui tes diagnostik five-tier tersebut akan didapatkan lebih banyak data tentang konsepsi siswa secara lebih mendalam (Fajriyyah \& Ermawati, 2020).

Berdasarkan penjabaran di atas, dapat dikatakan bahwa tier kelima pada tes diagnostik five-tier dapat mendeteksi level konsepsi siswa. Tabel 1 menunjukkan kategori level konsepsi yang dimiliki oleh siswa.

Tabel 1. Level konsepsi siswa pada tes diagnostik five-tier (Anam, 2019)

\begin{tabular}{|c|c|c|c|c|c|c|}
\hline \multirow{2}{*}{ No } & \multicolumn{5}{|c|}{ Jawaban Tier ke- } & \multirow{2}{*}{$\begin{array}{c}\text { Level } \\
\text { Konseps }\end{array}$} \\
\hline & 1 & 2 & 3 & 4 & 5 & \\
\hline \multirow{5}{*}{1} & \multirow{5}{*}{ B } & \multirow{5}{*}{ Y } & \multirow{5}{*}{ B } & \multirow{5}{*}{$\mathrm{Y}$} & $S D / S C$ & $S C$ \\
\hline & & & & & $P D / P C$ & $A S C$ \\
\hline & & & & & $M D / M C$ & $V$ \\
\hline & & & & & $U D / U C$ & $L K$ \\
\hline & & & & & $N D / N C$ & $U n C$ \\
\hline 2 & B & Y & B & TY & & \\
\hline 3 & B & TY & B & Y & & \\
\hline 4 & B & TY & $\mathrm{B}$ & TY & & \\
\hline 5 & B & $Y$ & $\mathrm{~S}$ & $\mathrm{TY}$ & $P D / P C /$ & \\
\hline 6 & B & $Y$ & $S$ & $Y$ & $M D / M C$ & \\
\hline 7 & B & $\mathrm{TY}$ & $\mathrm{S}$ & $\mathrm{Y}$ & / & $L K$ \\
\hline 8 & B & TY & $\mathrm{S}$ & $\mathrm{TY}$ & $U D / U C /$ & \\
\hline 9 & S & $Y$ & B & Y & $N D / N C$ & \\
\hline 10 & $\mathrm{~S}$ & $\mathrm{Y}$ & B & $\mathrm{TY}$ & & \\
\hline 11 & S & TY & B & $Y$ & & \\
\hline 12 & $\mathrm{~S}$ & TY & B & TY & & \\
\hline 13 & $\mathrm{~S}$ & $Y$ & $\mathrm{~S}$ & $\mathrm{TY}$ & $P D / P C /$ & \\
\hline 14 & $\mathrm{~S}$ & TY & $S$ & Y & $M D / M C$ & \\
\hline & & & & & / & $N U$ \\
\hline 15 & $S$ & TY & $S$ & TY & $U D / U C /$ & \\
\hline & & & & & $N D / N C$ & \\
\hline 16 & S & $Y$ & $S$ & Y & $M D / M C$ & $M S C$ \\
\hline
\end{tabular}

Gambar/Kesimpulann sesuai dengan konsep

Sebagian

Gambar/Kesimpulan sesuai dengan

konsep

Gambar/Kesimpulan bersifat miskonsepsi Gambar/Kesimpulan tidak dapat didefinisikan

Tidak ada gambar/kesimpulan

Paham konsep

Hampir paham

konsep

Tidak dapat

dikodekan

LK Lack of Knowledge Kurang paham konsep

NU No Understand a Concept Tidak paham konsep MSC Misconception Miskonsepsi

Berdasarkan fakta adanya miskonsepsi yang dialami oleh siswa pada materi GHS di atas, maka diperlukan suatu upaya untuk mendeteksi adanya miskonsepsi tersebut. Oleh karena itu dalam penelitian ini, Penulis bermaksud untuk melaporkan hasil pengembangan instrumen tes diagnostik level konsepsi berformat five tier untuk materi GHS, mengingat instrumen tersebut belum tersedia secara standar. Selain itu, penelitian ini juga memaparkan hasil uji validitas, reliabilitas dan uji coba terbatasnya pada sejumlah siswa tingkat SMA.

\section{METODE PENELITIAN}

Penelitian ini termasuk dalam jenis penelitian pengembangan, yaitu mengembangkan instrumen tes diagnostik five-tier untuk materi GHS sehingga mengadopsi metode Research and Development $(R \& D)$. Metode research dilakukan 
dengan mengkaji potensi miskonsepsi pada dua buku sumber, yaitu University Physics with Modern Physics 13th Edition (Young \& Freedman, 2013) dan Physics: Principles with Applications, 7th Edition (Giancoli, 2014).

Tabel 2. Rekapitulasi dari salah satu potensi miskonsepsi siswa terhadap materi GHS

\begin{tabular}{|c|c|c|}
\hline $\begin{array}{c}\text { Sub } \\
\text { Konsep }\end{array}$ & Konsep yang Benar & $\begin{array}{c}\text { Potensi } \\
\text { Miskonsepsi }\end{array}$ \\
\hline $\begin{array}{l}\text { Kelajuan } \\
\text { maksimum } \\
\text { bandul }\end{array}$ & 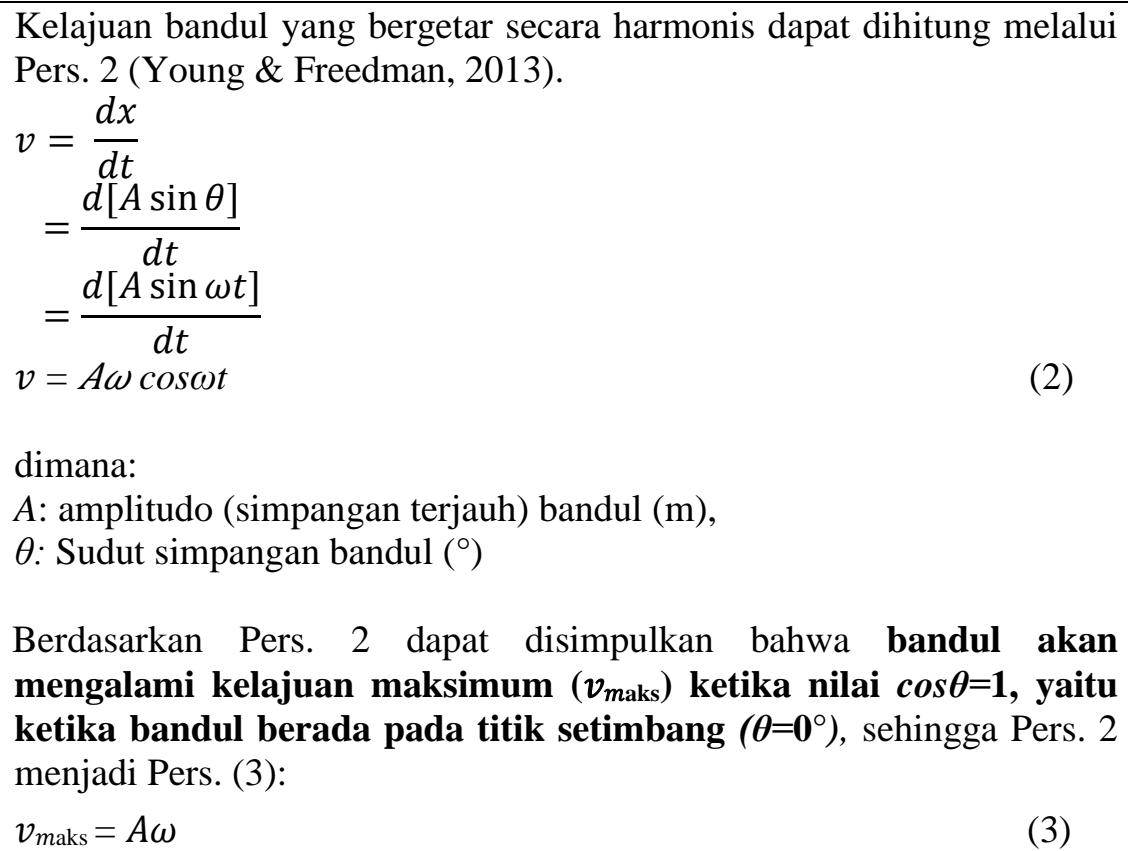 & $\begin{array}{l}\text { Siswa } \\
\text { menganggap } \\
\text { bahwa bandul } \\
\text { akan } \\
\text { mengalami } \\
\text { kelajuan } \\
\text { maksimum } \\
\text { ketika bandul } \\
\text { mulai } \\
\text { bergerak. }\end{array}$ \\
\hline
\end{tabular}

Setelah potensi miskonsepsi teridentifikasi, maka tahap development siap dilakukan. Metode development tersebut diawali dengan menyusun Draf 1 berupa instrumen soal tes diagnostik yang bersifat open-ended questions. Instrumen tersebut diuji cobakan pada 20 orang siswa SMA di wilayah Mojokerto, Sidoarjo dan Surabaya dengan tujuan menjaring alasan yang mungkin diutarakan oleh siswa uji untuk menjawab pertanyaan pada tier 1 . Hasil dari uji coba tersebut dijadikan acuan untuk merevisi Draf 1 sehingga menjadi Draf 2. Draf 2 kemudian divalidasi internal oleh dua orang Dosen Validator di Jurusan Fisika UNESA yang ditunjuk. Tujuan dari tahap tersebut adalah untuk memperoleh feedback tentang validitas internal yang meliputi tiga aspek, yaitu: isi, konstruk (kesesuaian antara butir soal dengan kompetensi dasar), dan bahasa. Hasil validitas internal tersebut diolah dengan Pers. 4 (Arikunto, 2016).

$$
P=\frac{S_{R}}{N \cdot P_{A} \cdot R} \times 100 \%
$$

Setelah itu mengkaji potensi miskonsepsi siswa dan merekapnya. Salah satu hasil rekapitulasi potensi miskonsepsi tersebut tersedia pada Tabel 2. 
alasan yang benar dan pertanyaan pada tier kelima dijawab dengan salah. $\% F P$ dan $F N$ tersebut dapat dihitung menggunakan Pers. 5 (Jannah \& Ermawati, 2019).

$$
\% X=\frac{\sum X}{\sum_{i t e m s} \times \sum_{P D}} \times 100 \%
$$

Dimana, $\sum X$ adalah jumlah $F P$ atau $F N$; $\sum$ items adalah jumlah butir soal yang dikembangkan (16 butir) dan $\sum P D$ adalah jumlah siswa yang menjadi responden (21 siswa). Nilai validitas instrumen isi dikatakan terpenuhi apabila nilai $F P$ dan $F N$ masing-masing $<10 \%$.

Sedangkan \% validitas empiris konstruk didapatkan melalui persamaan korelasi Pearson Product Moment dan reliabilitasnya didapatkan melalui persamaan koefisien Alpha Cronbach (Arikunto, 2016).

Setelah tingkat validitas dan reliabilitas Draf Final diperoleh, maka instrumen tersebut siap diuji cobakan pada siswa. Uji coba yang dimaksud dilakukan kepada 18 orang siswa SMA lainnya di wilayah Gresik, Surabaya dan Sidoarjo yang telah menerima materi GHS pada semester sebelumnya. Tujuan dari tahap ini adalah untuk mengetahui level konsepsi dari masing-masing siswa uji terhadap materi GHS. Apabila ditemukan miskonsepsi, maka penyebab misonsepsi tersebut akan dapat dideteksi.

\section{HASIL DAN PEMBAHASAN}

\section{Pengembangan Instrumen}

Tabel 3 menunjukkan salah satu contoh butir soal tes diagnostik konsepsi five-tier yang telah dikembangkan dalam penelitian ini. Adapun ke15 belas sisa butir soal lainnya sengaja tidak disertakan dalam makalah ini, mengingat pada saat bersamaan, instrumen tes diagnostik tersebut sedang diusulkan hak cipta ke Direktorat Jendral Kekayaan Intelektual (DJKI) Kemenkumham RI.

Tabel 3. Salah satu butir soal hasil pengembangan instrumen pada penelitian ini

\section{Tier Pertanyaan dan butir pilihan jawaban} Perhatikan gambar di bawah ini

Tier

1

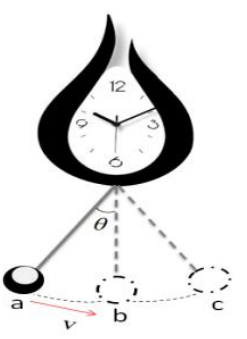

Gambar 1. Bandul jam dinding yang berayun

Dimas sedang mengamati gerakan bandul jam dinding di ruang tamu. Bandul jam dinding tersebut berayun seperti pada Gambar 1 sehingga bandul jam dinding tersebut akan memiliki energi yang bergantung pada kelajuan (energi kinetik). Menurut Anda, energi kinetik akan bernilai maksimum saat bandul jam dinding tersebut berada pada posisi?
A. a
B. $b$
C. $\mathrm{c}$
D. a dan c
E. semua titik

Tier

\section{Tingkat keyakinan jawaban:}

2

A. Yakin

B. Tidak yakin

Apakah alasan Anda memilih jawaban tersebut?

A. Energi kinetik bandul jam dinding bernilai maksimum saat mulai bergerak karena saat itu kelajuan bandul jam dinding bernilai maksimum (Pemikiran humanistik).

B. Energi kinetik bandul jam dinding bernilai maksimum saat berada pada posisi setimbang karena saat itu

Tier kelajuan bandul jam dinding bernilai

C. Energi kinetik yang dialami oleh bandul jam dinding pada setiap posisi gerak adalah sama (Pemikiran asosiatif).

D. Energi kinetik bandul jam dinding bernilai maksimum saat berada pada simpangan terjauh karena saat itu kelajuan bandul jam dinding bernilai maksimum (Prakonsepsi).

E. Energi kinetik bandul jam dinding bernilai maksimum selama bandul 
jam dinding tersebut sedang berayun (Intuisi yang salah).

F. Energi kinetik bernilai maksimum saat bandul jam dinding berada pada posisi terjauhnya (Reasoning yang salah).

\begin{tabular}{cl} 
Tier & Tingkat keyakinan alasan jawaban: \\
$\mathbf{4}$ & A. Yakin \\
& B. Tidak yakin \\
& Tuliskan 3 faktor yang mempengaruhi \\
& energi kinetik yang dialami oleh \\
Tier & bandul jam dinding di atas! \\
$\mathbf{5}$ & Massa bandul \\
& Kecepatan sudut \\
& Amplitudo \\
\hline
\end{tabular}

Keterangan: $\square$ menyatakan kunci jawaban

Berdasarkan Tabel 3, tier 1 terdiri dari pertanyaan beserta 4 opsi jawaban salah dan 1 opsi jawaban benar. Tier 2 menyatakan tingkat keyakinan atas jawaban yang telah dipilih oleh siswa pada tier 1 . Tier 3 terdiri dari alasan memilih jawaban pada tier 1 beserta 5 opsi jawaban yang disusun berdasarkan potensi miskonsepsi yang berasal dari diri siswa (ditulis dengan huruf berwarna merah) dan 1 opsi jawaban benar. Tier 4 menyatakan tingkat keyakinan alasan jawaban yang dipilih oleh siswa pada tier 3. Sedangkan tier 5 berupa pertanyaan konfirmasi yang meminta siswa untuk menggambar atau menarik kesimpulan terkait sub konsep yang ditanyakan. Tier 5 tersebut dapat mengantisipasi tebakan siswa dalam menjawab tier 1-4 (Salsabila \& Ermawati, 2020). Opsi jawaban dengan highlight berwarna kuning menunjukkan opsi jawaban yang benar.

Pada tier 3, opsi A termasuk pemikiran humanistik karena siswa menganggap bahwa bandul jam dinding yang bergerak secara harmonis sama dengan bola yang menggelinding dari permukaan bidang miring, dimana keduanya akan mengalami Energi kinetik maksimum ketika pertama kali bergerak dan Energi kinetik tersebut akan bernilai minimum ketika keduanya akan berhenti bergerak. Opsi C merupakan pemikiran asosiatif karena siswa menghubungkan konsep Energi kinetik bandul jam dinding yang bergerak harmonis dengan Energi kinetik benda yang bergerak lurus beraturan dimana Energi kinetiknya selalu sama pada setiap posisi geraknya. Opsi D adalah prakonsepsi karena siswa menganggap bahwa ketika bandul jam dinding berada pada simpangan terjauh, maka bandul jam dinding tersebut akan memiliki kelajuan yang bernilai maksimum sehingga Energi kinetiknya akan bernilai maksimum pula. Opsi E merupakan intuisi yang salah karena siswa menganggap bahwa bandul jam dinding yang sedang berayun secara harmonis akan selalu memiliki Energi kinetik maksimum sedangkan bandul jam dinding yang tidak berayun (diam) akan memiliki Energi kinetik minimum. Sedangkan opsi $\mathrm{F}$ adalah reasoning yang salah karena siswa menganggap bahwa bandul jam dinding akan memiliki Energi kinetik maksimum ketika bandul jam dinding tersebut berada pada posisi terjauh. Sementara menurut konsep Fisika, Energi kinetik bandul jam dinding akan bernilai maksimum ketika bandul jam dinding tersebut memiliki Kelajuan yang bernilai maksimum pula, yaitu ketika bandul jam dinding berada pada posisi setimbang (Opsi jawaban B) (Giancoli, 2014).

\section{Uji validitas dan reliabilitas}

Tabel 4-7 memberikan rekapitulasi hasil validasi internal, validitas eksternal empiris isi dan konstruk serta reliabilitas untuk ke-16 butir tes diagnostik yang dikembangkan dalam penelitan ini.

Tabel 4. $\%$ dan kriteria validitas internal

\begin{tabular}{cccc}
\hline No & Aspek & Presentase (\%) & Kriteria \\
\hline 1 & Isi & 94 & Sangat valid \\
2 & Konstruk & 85 & Sangat valid \\
3 & Bahasa & 100 & Sangat valid \\
Rata-rata & 93 & Sangat valid \\
\hline
\end{tabular}

Berdasarkan Tabel 4, Draf 2 adalah sangat valid karena berada pada rentang 81-100\% (Riduwan \& Akdon, 2013). Dengan demikian, Draf 2 dapat dilanjutkan menjadi Draf Final. Setelah itu dilakukan validitas eksternal terhadap Draf Final. 
Tabel 5. \% validitas eksternal empiris isi (FP \&

\begin{tabular}{|c|c|c|c|c|}
\hline \multicolumn{5}{|c|}{$F N)$} \\
\hline $\begin{array}{l}\text { No. } \\
\text { Soal } \\
\end{array}$ & $F P$ & $F N$ & $\sum \mathrm{PD}$ & $\sum$ soal $\times \sum \mathrm{PD}$ \\
\hline 1 & 0 & 1 & \multirow{16}{*}{21} & \multirow{16}{*}{336} \\
\hline 2 & 0 & 0 & & \\
\hline 3 & 0 & 0 & & \\
\hline 4 & 0 & 2 & & \\
\hline 5 & 0 & 0 & & \\
\hline 6 & 1 & 0 & & \\
\hline 7 & 0 & 1 & & \\
\hline 8 & 0 & 1 & & \\
\hline 9 & 0 & 0 & & \\
\hline 10 & 0 & 1 & & \\
\hline 11 & 0 & 0 & & \\
\hline 12 & 0 & 0 & & \\
\hline 13 & 0 & 0 & & \\
\hline 14 & 0 & 2 & & \\
\hline 15 & 0 & 0 & & \\
\hline 16 & 0 & 0 & & \\
\hline Total & 2 & 8 & & \\
\hline$\%$ & $0,6 \%$ & $2,4 \%$ & & \\
\hline
\end{tabular}

Berdasarkan Tabel 5, \% FP dan FN Draf Final yang diperoleh secara berturut-turut adalah 0,6 dan 2,4 \%. Dengan demikian, Draf Final tersebut telah memenuhi kriteria validitas empiris isi karena \% FP dan FN <10 \% (Yuanita \& Suprapto, 2019).

Gambar 2 memberikan tangkapan layar data nilai $r_{\text {tabel }}$ yang digunakan untuk uji validitas empiris konstruk terhadap Draf Final. Mengingat jumlah siswa uji yang terlibat berjumlah 21 orang, maka dengan taraf signifikansi $5 \%$ didapatkan nilai $r_{\text {tabel }}=0,413$. Nilai tersebut selanjutnya dibandingkan dengan $r_{x y}$ yang diperoleh berdasarkan hasil penelitian ini.

\begin{tabular}{|c|c|c|}
\hline \multirow{2}{*}{$\begin{array}{c}d f . \\
\text { (degrees of freedom) } \\
\text { atau: } \\
d b .\end{array}$} & \multicolumn{2}{|c|}{ Banyak variabel yang dikorelasikan: } \\
\cline { 2 - 3 } (derajat bebas) & \multicolumn{2}{|c|}{2} \\
\cline { 2 - 3 } & Harga “ $r^{3}$ pada tarai signifikansi: \\
\cline { 2 - 3 } & $5 \%$ & $1 \%$ \\
\hline 21 & 0,413 & 0,526 \\
\hline 22 & 0,404 & 0,515 \\
23 & 0,396 & 0,505 \\
\hline
\end{tabular}

Gambar 2. Tangkapan layar nilai $r_{\text {tabel }}$ dengan derajat kebebasan 21-23 dan taraf signifikansi 5 \& $1 \%$ (Sudijono, 2014)
Tabel 6. Nilai $r_{x y}$ pada setiap butir soal beserta kriterianya

\begin{tabular}{cccc}
\hline No. & $\mathrm{r}_{\mathrm{xy}}$ & $\mathrm{r}_{\text {tabel }}$ & Kategori \\
Soal & 0,506 & & Valid \\
\hline 1 & 0,838 & & Valid \\
2 & 0,732 & & Valid \\
3 & 0,783 & & Valid \\
4 & 0,782 & & Valid \\
5 & 0,760 & & Valid \\
6 & 0,595 & & Valid \\
7 & 0,537 & 0,413 & Valid \\
8 & 0,782 & & Valid \\
9 & 0,849 & & Valid \\
10 & 0,848 & & Valid \\
11 & 0,832 & & Valid \\
12 & 0,701 & & Valid \\
13 & 0,747 & & Valid \\
14 & 0,609 & & Valid \\
15 & 0,619 & & Valid \\
16 & & & \\
\hline
\end{tabular}

Dengan membandingkan antara nilai $r_{x y}$ dengan $r_{\text {tabel }}$ pada Tabel 6 , maka didapatkan bahwa keenam belas butir soal pada Draf Final adalah valid, mengingat nilai $\mathrm{r}_{\mathrm{xy}}>\mathrm{rt}_{\mathrm{abel}}$ (Riduwan \& Akdon, 2013).

Tabel 7. Nilai $r_{\text {tabel }}$ Draf Final beserta kriterianya

\begin{tabular}{ccc}
\hline $\mathbf{r}_{11}$ & $\mathbf{r}_{\text {tabel }}$ & Kriteria \\
\hline 0,869 & 0,413 & Sangat tinggi \\
\hline
\end{tabular}

Berdasarkan Tabel 7, didapatkan bahwa nilai $\mathrm{r}_{11}>\mathrm{r}_{\text {tabel }}$ sehingga Draf Final sangat reliabel (Arikunto, 2016). Mengingat bahwa Draf Final sangat valid dan reliabel, maka draf tersebut siap untuk diuji cobakan. Seperti telah dijelaskan di atas, kegiatan uji coba instrumen tes diagnostik tersebut dilakukan kepada 18 orang siswa SMA lainnya yang telah diajarkan materi GHS pada semester sebelumnya, dimana ke-18 siswa tersebut dipilih secara acak dari SMA di wilayah Gresik, Surabaya dan Sidoarjo. Namun karena keterbatasan ruang yang diberlakukan untuk penulisan makalah ini, maka pada Tabel 8 hanya ditampilkan hasil ujicoba terhadap ke-7 siswa uji saja. 
Tabel 8. Rekapitulasi hasil uji coba terbatas terhadap 7 orang siswa

\begin{tabular}{|c|c|c|c|c|c|c|c|c|}
\hline \multirow{2}{*}{$\begin{array}{l}\overline{\bar{\sigma}} \\
\dot{n} \\
\dot{8}\end{array}$} & \multirow{2}{*}{ 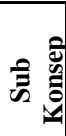 } & \multicolumn{7}{|c|}{ Level Konsepsi Siswa ke-* } \\
\hline & & 1 & 2 & 3 & 4 & 5 & 6 & 7 \\
\hline 1 & $\mathrm{a}$ & $N U$ & $\begin{array}{c}M S C \\
(\mathrm{H})\end{array}$ & $\begin{array}{c}M S C \\
(\mathrm{H})\end{array}$ & $L K$ & $L K$ & $L K$ & $L K$ \\
\hline 2 & b & $\begin{array}{c}M S C \\
\text { (I) }\end{array}$ & $L K$ & $L K$ & $L K$ & $L K$ & $L K$ & $L K$ \\
\hline 3 & $\mathrm{c}$ & $N U$ & $L K$ & $L K$ & $L K$ & $L K$ & $L K$ & $A S C$ \\
\hline 4 & d & $L K$ & $S C$ & $\begin{array}{c}M S C \\
(\mathrm{P})\end{array}$ & $S C$ & $S C$ & $S C$ & $L K$ \\
\hline 5 & $\mathrm{e}$ & $L K$ & $A S C$ & $L K$ & $L K$ & $L K$ & $A S C$ & $A S C$ \\
\hline 6 & f & $L K$ & $L K$ & $\begin{array}{c}M S C \\
\text { (A) }\end{array}$ & $L K$ & $L K$ & $L K$ & $N U$ \\
\hline 7 & $\mathrm{~g}$ & $L K$ & $\begin{array}{c}M S C \\
(\mathrm{P})\end{array}$ & $N U$ & $N U$ & $N U$ & $N U$ & $L K$ \\
\hline 8 & $\mathrm{~h}$ & $N U$ & $\begin{array}{c}M S C \\
(R)\end{array}$ & $N U$ & $\begin{array}{c}M S C \\
(\mathrm{R})\end{array}$ & $\begin{array}{c}M S C \\
(\mathrm{R})\end{array}$ & $\begin{array}{c}M S C \\
(\mathrm{R})\end{array}$ & $\begin{array}{c}M S C \\
(\mathrm{P})\end{array}$ \\
\hline 9 & $\mathrm{i}$ & $L K$ & $L K$ & $S C$ & $L K$ & $L K$ & $L K$ & $A S C$ \\
\hline 10 & j & $L K$ & $L K$ & $L K$ & $L K$ & $L K$ & $L K$ & $S C$ \\
\hline 11 & $\mathrm{k}$ & $L K$ & $\begin{array}{c}\text { MS } \\
\text { C } \\
(\mathrm{H})\end{array}$ & $N U$ & $L K$ & $\begin{array}{c}M S C \\
\text { (A) }\end{array}$ & $\begin{array}{c}M S C \\
\text { (A) }\end{array}$ & $N U$ \\
\hline 12 & 1 & $N U$ & $\begin{array}{c}M S C \\
\text { (I) }\end{array}$ & $L K$ & $\begin{array}{c}M S C \\
\text { (I) }\end{array}$ & $\begin{array}{c}M S C \\
\text { (I) }\end{array}$ & $L K$ & $\begin{array}{c}M S C \\
\text { (I) }\end{array}$ \\
\hline 13 & $\mathrm{~m}$ & $L K$ & $L K$ & $L K$ & $L K$ & $L K$ & $L K$ & $A S C$ \\
\hline 14 & $\mathrm{n}$ & $\begin{array}{c}M S C \\
\text { (A) }\end{array}$ & $A S C$ & $L K$ & $S C$ & $S C$ & $S C$ & $L K$ \\
\hline 15 & o & $\begin{array}{c}M S C \\
(\mathrm{P}) \\
\end{array}$ & $N U$ & $N U$ & $L K$ & $N U$ & $L K$ & $L K$ \\
\hline 16 & $\mathrm{p}$ & $\begin{array}{c}M S C \\
(\mathrm{H})\end{array}$ & $N U$ & $L K$ & $N U$ & $N U$ & $N U$ & $L K$ \\
\hline
\end{tabular}

Keterangan:

$\begin{array}{rll}* & : & \text { Ditentukan berdasarkan Tabel } 1 \text { kolom ke-7 } \\ \mathrm{a} & : & \text { Kelajuan maksimum bandul } \\ \mathrm{b} & : & \text { Gaya pemulih bandul } \\ \mathrm{c} & : & \text { Energi kinetik bandul } \\ \mathrm{d} & : & \text { Energi kinetik pegas } \\ \mathrm{e} & : & \text { Energi potensial bandul } \\ \mathrm{f} & : & \text { Energi potensial pegas } \\ \mathrm{g} & : & \text { Energi mekanik bandul } \\ \mathrm{h} & : & \text { Energi mekanik pegas } \\ \mathrm{i} & : & \text { Hubungan antara massa dengan periode bandul } \\ \mathrm{j} & : & \text { Hubungan antara panjang tali dengan periode } \\ \mathrm{k} & : & \text { Periode pegas } \\ \mathrm{l} & : & \text { Hubungan antara massa dengan frekuensi } \\ & : & \text { Handul } \\ \mathrm{m} & : & \text { Hubungan antara panjang tali dengan frekuensi } \\ \mathrm{n} & : & \text { Frekuensi pegas } \\ & : & \text { Hubungan antara amplitudo pegas dengan } \\ \mathrm{o} & & \text { periode } \\ & : & \text { Hubungan antara amplitudo pegas dengan } \\ \mathrm{p} & & \text { frekuensi } \\ \mathrm{A} & : & \text { Pemikiran Asosiatif } \\ \mathrm{H} & : & \text { Pemikiran Humanistik } \\ \mathrm{I} & : & \text { Intuisi yang salah }\end{array}$

\section{P : Prakonsepsi \\ $\mathrm{R}$ : Reasoning yang salah}

Berdasarkan data pada Tabel 8 , secara umum dapat diketahui bahwa setiap siswa memiliki level konsepsi yang berbeda pada setiap sub konsep (Winarti \& Budiarti, 2020).

Dalam penelitian ini, Siswa 2, 4, 5 dan 7 dikategorikan misconception (MSC) akibat intuisi yang salah terhadap Sub Konsep 1 (Hubungan antara massa dengan frekuensi bandul) karena mereka menganggap bahwa semakin besar massa bandul, maka gerakan yang dihasilkan oleh bandul tersebut akan semakin lambat sehingga akan dihasilkan frekuensi getaran yang semakin kecil. Sementara menurut konsep Fisika, frekuensi bandul dipengaruhi oleh panjang tali yang digunakan dan percepatan gravitasi di tempat itu, namun tidak dipengaruhi oleh massa bandul yang digunakan. Gambar 3 menunjukkan bukti jawaban dari salah satu siswa yang miskonsepsi terhadap Sub Konsep 1 tersebut.

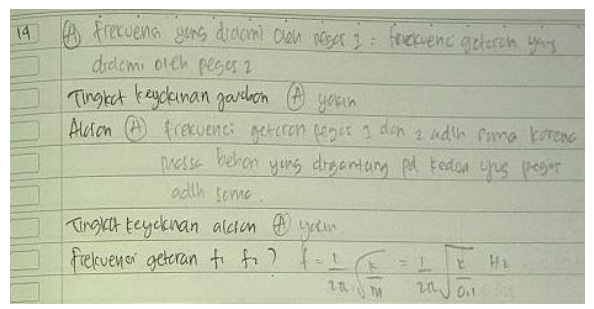

Gambar 3. Jawaban dari salah satu siswa uji yang misconception pada Sub Konsep Hubungan antara massa dengan frekuensi bandul (1).

Pada Sub Konsep d (Energi kinetik pegas), 4 dari 7 siswa uji tergolong scientific conception $(S C)$. Banyaknya siswa uji yang memiliki level konsepsi tersebut dapat terjadi karena tier kelima hanya meminta siswa untuk menuliskan persamaan Energi kinetik pegas sehingga pertanyaan tersebut akan mudah dijawab (Khairunnisa, Djudin, \& Oktavianty, 2018) oleh siswa yang mengingat persamaan Energi kinetik pegas. Gambar 4 menunjukkan bukti jawaban dari salah satu siswa yang tergolong scientific conception terhadap Sub Konsep Energi kinetik pegas tersebut. Selain itu, seperti terlihat pada Tabel 8, dari 16 sub konsep yang diujikan pada materi GHS tersebut, setidaknya terdapat $50 \%$ dari total siswa uji telah terdeteksi mengalami lack of knowledge (LK). 


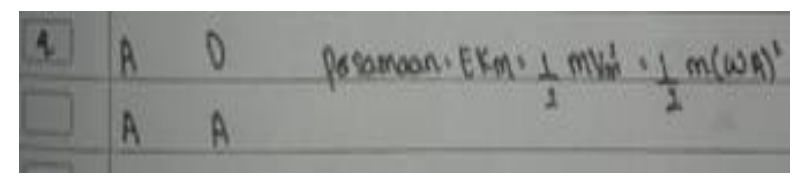

Gambar 4. Jawaban dari salah satu siswa uji yang tergolong scientific conception pada Sub Konsep d (Energi kinetik pegas)

Penelitian relevan yang mengidentifikasi miskonsepsi siswa terhadap konsep GHS dilakukan oleh Khairunnisa, dkk. (2018). Penelitian tersebut berfokus untuk melakukan remediasi siswa menggunakan model Conceptual Change Tipe ECIRR dalam Pembelajaran Getaran Harmonis Sederhana. Dalam penelitian tersebut, hasil pretest menunjukkan bahwa 23 dari 38 siswa SMA mengalami miskonsepsi pada sub materi hubungan antara amplitudo dengan frekuensi getaran.

Selain itu, penelitian lainnya yang juga mengidentifikasi miskonsepsi siswa terhadap konsep GHS dilakukan oleh Kamelia (2019). Penelitian tersebut menganalisis level konsepsi siswa terhadap konsep GHS menggunakan CRI (Certainty of Response Index) termodifikasi. Hasil dari penelitian tersebut menunjukkan bahwa 34,89 \% siswa paham konsep; 22,24\% siswa paham konsep sebagian; 12,65 \% siswa tidak paham konsep; 12,01 siswa tidak dapat dikodekan dan 9,21\% siswa miskonsepsi.

\section{KESIMPULAN}

Penelitian ini berhasil mengembangkan 16 butir instrumen tes diagnostik five-tier untuk materi GHS yang memenuhi aspek validitas internal, eksternal dan reliabilitas sehingga instrumen tersebut dapat digunakan untuk mendeteksi level konsepsi siswa tingkat SMA terhadap materi GHS. Hasil uji coba terbatas yang dilakukan terhadap 7 orang siswa telah mampu menunjukkan level konsepsi yang dimiliki oleh masing-masing siswa tersebut. Dengan kata lain, instrumen yang dikembangkan telah berfungsi sebagaimana mestinya.

\section{DAFTAR PUSTAKA}

Ali, M. (2019). Analisis Miskonsepsi Siswa Berdasarkan Gender dalam Pembelajaran Fisika dengan Menggunakan Tes Diagnostik Two-Tier di Kotabaru.
CENDEKIA: Jurnal Ilmiah Pendidikan, Volume 7 No. 1, 59-66.

Anam, R. S. (2019). Developing a Five-Tier Diagnostic Test to Identify Students' Misconceptions in Science: An Example of the Heat Transfer Concepts. Elementary Education Online, 18 (03), 1014-1029.

Arikunto, S. (2016). Dasar-Dasar Evaluasi Pendidikan (Edisi 2). Jakarta: PT. Bumi Aksara.

Azizah, U., Parno, \& Supriana, E. (2019). Identifikasi Penguasaan Konsep Fisika Siswa SMA Kelas XI dan XII pada Materi Suhu dan Kalor . Jurnal Pendidikan: Teori, Penelitian, dan Pengembangan, 4(4), 484-490.

Bayuni, T., Sopandi, W., \& Sujana , A. (2018). Identification Misconception of Primary School Teacher Education Students in Changes of Matters using a Five-Tier Diagnostic Test. Physics Conference Series, 1031 (01), 012086.

Fajriyyah, N. S., \& Ermawati, F. U. (2020). The Validity and Reliability of Five-Tier Diagnostic Test for Kinetic Theory of Gases. Jurnal Inovasi Pendidikan Fisika, 09(02), 126-132.

Giancoli, D. C. (2014). Physics: Principles with Applications, 7th Edition. New York: Pearson Education, Inc.

Jannah, E. M., \& Ermawati, F. U. (2019). Validitas dan Reliabilitas Instrumen Tes Diagnostik Berformat Four-Tier untuk Materi Dinamika Rotasi dan Kesetimbangan Benda Tegar. Inovasi Pendidikan Fisika Vol. 08 No. 02, 560564.

Kamelia, F. (2019). Analisis Konsepsi Siswa Kelas X pada Materi Getaran Harmonis dengan CRI (Certainty of Response Index) Termodifikasi. (Skripsi). Semarang: Fakultas Sains dan Teknologi Universitas Islam Negeri Walisongo.

Khairunnisa, Djudin, T., \& Oktavianty, E. (2018). Mengintegrasikan Remediasi Miskonsepsi Menggunakan Model Conceptual Change Tipe ECIRR dalam Pembelajaran Getaran Harmonis Sederhana. Jurnal Pendidikan dan Pembelajaran Khatulistiwa, 7(5). 
Lely, H., Silitonga, H. T., \& Oktavianty, E. (2018). Pengembangan Tes Diagnostik pada Materi Hukum Newton di SMA. Jurnal Pendidikan dan Pembelajaran Khatulistiwa, 7(7).

Maulini, S., Kurniawan, Y., \& Muliyani, R. (2017). The Three Tier-Test untuk Mengungkap Kuantitas Siswa yang Miskonsepsi pada Konsep Konstanta Pegas. . Jurnal Ilmu Pendidikan Fisika Volume 2 Number 2, 28-29.

Munawaroh, R., \& Setyarsih, W. (2016). Identifikasi Miskonsepsi Siswa dan Penyebabnya pada Materi Alat Optik Menggunakan Three-tier Multiple Choice Diagnostic Test. Jurnal Inovasi Pendidikan Fisika, 05(02), 79-81.

Prastiwi, V. D., Parno, \& Wisodo, H. (2018). Identifikasi pemahaman konsep dan penalaran ilmiah siswa SMA pada. Momentum: Physics Education Journal, 2 (2), 2018, 56-63.

Pratiwi , H. Y. (2016). Pengembangan Instrumen Tes Pilihan Ganda untuk Mengidentifikasi Karakteristik Konsep Termodinamika Mahasiswa Prodi Pendidikan Fisika Universitas Kanjuruhan Malang. Jurnal Inspirasi Pendidikan Universitas Kanjuruhan Malang Volume 6 Nomor 2, 842-850.

Qonita, M., \& Ermawati, F. U. (2020). The Validity and Reliability of Five-Tier Conception Diagnostic Test for Vector Concepts. Jurnal Inovasi Pendidikan Fisika, 09(03), 459-465.

Rafiqah, Amin, F., \& Wayong, M. (2019). Pengaruh Learning Cycle Berbasis Metode Konflik Kognitif untuk Meningkatkan Pemahaman Konsep Fisika. Jurnal Pendidikan Fisika Vol. 7 No. 2, September 2019, 133-139.

Ramadhan, G., Dwijananti, P., \& Wahyuni, S. (2018). Analisis Kemampuan Berpikir Tingkat Tinggi (High Order Thinking Skills) Menggunakan Instrumen Two Tier Multiple Choice Materi Konsep dan Fenomena Kuantum Siswa SMA di Kabupaten Cilacap . Unnes Physics Education Journal 7 (3), 86-90.
Riduwan, \& Akdon. (2013). Rumus dan Data dalam Analisis Statistika. Bandung: Alfabeta.

Salsabila, F. N., \& Ermawati, F. U. (2020). Validity and Reliability of Conception Diagnostic Test Using FiveTier Format for Elasticity Concepts. . Inovasi Pendidikan Fisika, 09(03), 439-446.

Sari, A. L., Parno, \& Taufiq, A. (2018). Pemahaman Konsep dan Kesulitan Siswa SMA pada Materi Hukum Newton . Jurnal Pendidikan: Teori, Penelitian, dan Pengembangan Volume:3 Nomor:10, 1323-1330.

Sudijono, A. (2014). Pengantar Statistik. Jakarta: Rajawali Pers.

Utari, J. I., \& Ermawati, F. U. (2018). Pengembangan Instrumen Tes Diagnostik Miskonsepsi Berformat Four-Tier untuk Materi Suhu, Kalor dan Perpindahannya. Jurnal Inovasi Pendidikan Fisika, 07(03), 434-439.

Winarti, W., \& Budiarti, I. S. (2020). Diagnostik Konsepsi Siswa pada Materi Suhu dan Kalor. Jurnal Ilmu Pendidikan Indonesia Vol. 8 No. 3, 136-146.

Young, H. D., \& Freedman, R. A. (2013). University Physics with Modern Physics 13th Edition. New York: PearsonAddison Wesley.

Yuanita, Z., \& Suprapto, N. (2019). Analisis Kualitas Instrumen Four-Tier Diagnostic Test untuk Mengidentifikasi Profil Konsepsi Siswa pada Materi Teori Kinetik Gas. Jurnal Inovasi Pendidikan Fisika Vol. 08 No. 03, 830-834.

Zafitri, R. E., Fitriyanto, S., \& Yah, F. (2018). Pengembangan Tes Diagnostik untuk Miskonsepsi pada Materi Usaha dan Energi Berbasis Adobe Flash Kelas XI di MA NW Samawa Sumbawa Besar Tahun Ajaran 2017/2018. Jurnal Kependidikan, 2(2), 19-34. 